\title{
Continuous Cover Forestry Practitioners in a Clear-cutting- oriented System: Assessing the Potential to Foster the Practice
}

\author{
Maie Kiisel ${ }^{1} \cdot$ Liina Remm² $^{\mathbb{D}}$
}

Accepted: 7 January 2022 / Published online: 30 January 2022

(c) Steve Harrison, John Herbohn 2022

\begin{abstract}
Recently, changes in society have brought about the rediscovery of continuous cover forestry (CCF) as a forest management approach that helps to create multifunctional forests. However, the practice of CCF is only used in a relatively small area in the world, and its development potential is unclear. We studied the potential of forest owners practising CCF to act as niche experimenters to provide clearcutting-oriented Estonian forestry with experience for the development of CCF for specific needs. We adopt a multi-level perspective of socio-technical transitions, which proposes that forest owners' silvicultural choices develop and are stabilised in a complex, change-resistant and cross-sectoral framework that is formed by actors' networks, material artefacts and rules. The spread of the alternative silvicultural approach depends on the susceptibility of this framework, but also on owners' ability to form experimental niches: protected "incubation rooms" of change. To explore that potential, we visited eighteen forests and interviewed their owners to study their experiences in the enhancement of CCF. Our qualitative analysis demonstrates that the wider adoption of CCF is hindered due to several lock-in mechanisms in Estonian forestry but supported by related sectors. Some owners can apply CCF even within the present forestry framework due to their particular social embedding. However, it is unlikely that forest owners will start using CCF unless the forestry framework changes. We propose an analytical tool to enforce experimental CCF niche formation among the forest owners, as the necessity to apply $\mathrm{CCF}$ in the nearest future may increase.
\end{abstract}

Keywords Continuous cover forestry $\cdot$ Sustainable forest management $\cdot$ Multifunctional forest $\cdot$ Alternatives to clear-cutting $\cdot$ Forest owners $\cdot$ Multi-level perspective 


\section{Introduction}

Forests serve different social aims: large areas have been prioritised specifically for timber production, others for biodiversity or recreation, but most forests are treated as multifunctional (Lindenmayer et al. 2012). To achieve those multiple aims and cope with various natural conditions, forest owners can consider a diverse array of silvicultural approaches. One of these is continuous cover forestry (CCF). This term is sometimes considered to include several silvicultural systems, e.g. shelterwood systems. Nevertheless, here we focus on uneven-aged stands managed with singletree and group selection cuttings but excluding high-grading with selective cuttings. Compared to even-aged forestry, CCF is typically a low-input silvicultural approach that induces fewer fundamental reorganisations in the forest ecosystem and thus could stabilise the functioning of intensively managed forest landscapes (Kuuluvainen and Gauthier 2018). CCF can enhance sustainable forest management including various ecosystem services, but the current application of CCF is below its potential (Puettmann et al. 2015, Nieminen et al. 2018, Eyvindson et al. 2021, Kim et al. 2021). This justifies the search for opportunities to promote a wider application of CCF among forest owners.

To understand the opportunities of forest owners to prepare for such a change in forestry we apply the multi-level perspective (MLP) of socio-technical transitions as analytical framework (Geels 2002, 2004). In forestry research, innovation systems are usually addressed as institutional learning and interaction processes, region or value-chain (see, e.g. Weiss et al. 2017, Hayter and Clapp 2020, Lovrić and Lovrić 2020). The MLP framework does not set such boundaries and magnifies the role of non-institutional agents (such as forest owners and their social embedding), and especially end-users (those who benefit from multifunctional forests) (Geels 2004). A central position in this framework is given to the rule regime that is not limited to a particular sector (such as forestry) ${ }^{1}$. It is instead in a continuous co-evolutionary process between its sub-regimes: technology development, scientific research, policy formation, socio-cultural structures, and user-and-market networks (Fig. 1; Table 1).

The rule regime sensu Geels (2004) consists of three types of intermingled and inseparable rules: formal (written rules such as forestry laws, development plans), normative (cultural values, responsibilities, role expectations) and cognitive (concepts, myths, analytical frameworks). The rules help to organise and guide the activities of actors (this claim is, however, contested by Sorrell, 2018) and accommodate the use of physical (technological) artefacts in social processes.

The rule regime is, however, not something coherent and stable. It evolves as the regime actors need to respond to broader challenges (so-called landscape challenges, like climate change and ecological degradation) that cannot be solved by the means available within the incumbent rule regime. It may also evolve due to the

\footnotetext{
${ }^{1}$ The term 'forest regime' is used also in forest governance research. Despite its rich interpretation opportunities (Giessen 2013) we can say that this concept is similar to a regime defined in MLP network by its focus on actors networks and rules, but different by its focus on a particular sector (forestry) and on legal ties between institutions. The term lacks attention to non-institutional agents. To differentiate these terms, we stick to 'forestry rule regime' in this text. The focus of MLP approach is on system transformations, not on political decision-making.
} 


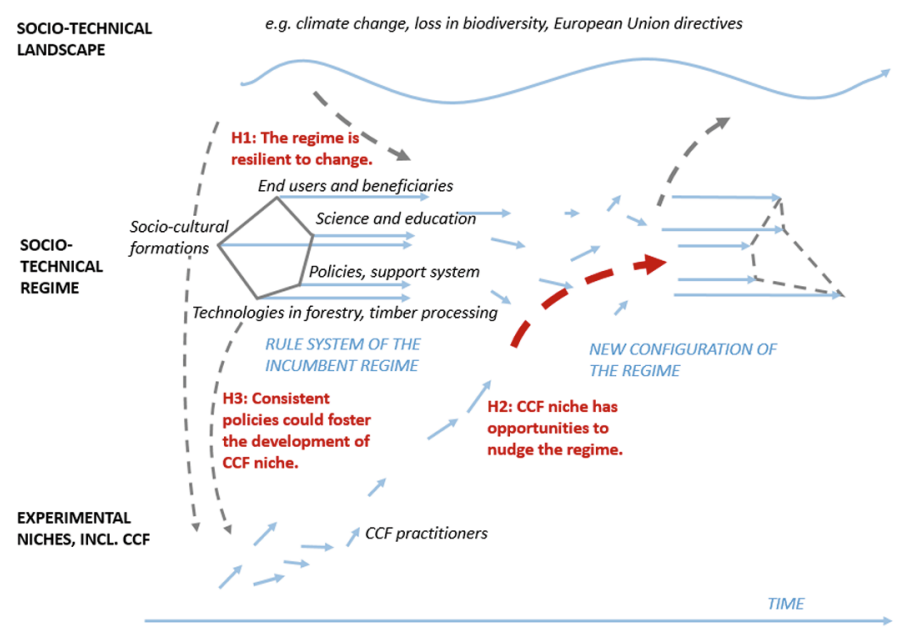

Fig. 1 The research hypotheses (in red) in the context of the MLP framework. Modified from Geels 2004. $\mathrm{CCF}$ - continuous cover forestry

discoveries or improvements created in experimental niches (new uses for the forest, re-invented management methods). We use MLP approach, as the needs that emanate from ecological crisis (macro challenge) resonate well with micro experimentations of the few CCF practitioners. The plea of MLP researchers (Geels and Schot 2007, Geels et al. 2014) is that transitions to sustainability can and should be supported by shaping the incumbent regime rules with special attention to niche experimenters (e.g., peripheral, non-institutional practitioners who operate in protected 'incubation rooms' of change). Therefore, we look at the forestry rule regime and its relations to present-day CCF practitioners.

In this paper, we analyse Estonian socio-technical regime of forestry and ask what can be done to support the practice of CCF. We also study the experiences of private forest owners applying $\mathrm{CCF}$ to understand their abilities to form an experimental niche to support the current clear-cutting-oriented system in the development of this practice (Fig. 1).

The differences between forest owners' social embeddings and aims (e.g., multiobjective owners, recreationists, conservationists) are hardly considered in policy projections (e.g., Eggers et al. 2014, Ficko et al. 2019). In forest policy, forest owners are represented as a homogenous group of people who take part in policy processes under the umbrella of forest associations, are organically bound to the forest industry and usually in opposition to environmental groups (see, e.g., Axelsson and Angelstam 2011, Eggers et al. 2014, Maier et al. 2014, Kleinschmit 2018, Weber 2018, Lindstad 2018). To avoid this misconception and understand what kind of changes a small group of forest owners applying CCF can evoke and how these are endorsed by the forestry rule regime, we looked for such forest owners in Estonia.

Among Estonian private forest owners, natural persons dominate. Only 5\% of forest owners are companies. However, $89 \%$ of forest owners have smaller forest 
properties than 20 ha (among those owners with $>1$ ha forest; Raudsaar et al. 2018). Therefore, irrespective of their ambitions, each owner separately has very little impact on forestry management approaches in general.

Firstly, based on document analysis, we investigated how the forestry rule regime in Estonia supports CCF, hypothesising, based on Geels et al. (2017), that the existing regime is resilient to change due to lock-in mechanisms in its various sub-regimes (H1). Secondly, we visited forest owners and analysed their opportunities to change the rules as niche experimenters (H2). Bringing these two analyses together, we proposed which support could foster the development of the CCF niche (H3).

\section{Materials and Methods}

We carried out the study in three broad steps according to the hypotheses (Fig. 2).

\section{Estonian Forestry Regime}

We analyse the opportunity to apply $\mathrm{CCF}$ in Estonia within a broader framework of multi-level perspective (Geels 2020) (H1). To find the factors that influence its application, we planned for the search of documents according to the partition of the socio-technical regime into sub-regimes: (i) socio-cultural formations, (ii) science and education, (iii) policies and support system, (iv) technology in forestry and timber processing, (v) end-users and beneficiaries (Fig. 1). We defined forestry equivalents to the elements of the socio-technical regime framework. Then we started looking for information about these elements (see Table 1). For example, to describe the socio-cultural sub-regime (i.e., social norms, social movements) we looked for public opinion surveys and media monitoring reports, and to study policy sub-regime, we

Fig. 2 Overview of the analysis flow encompassing the research hypotheses $(\mathrm{H})$

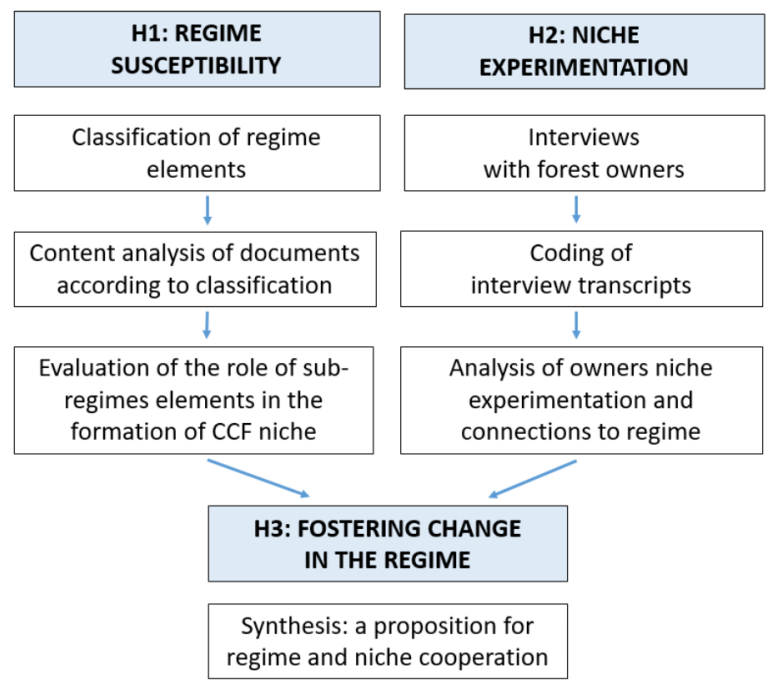


looked for legislative documents and policy guidelines. The analysis expanded during the process due to the additional nuances spotted in the documents and discussions with experts who referred to it. The types of documents we used were laws and regulations, official guidelines, statistics, media articles, scientific articles, research reports, textbooks, webpages, and public registries (Fig. 2). We used qualitative content analysis to define whether the source of information contains information about $\mathrm{CCF}$, and if so, what does it say about the appropriateness, need, availability, ways of application, results, and consequences of CCF. Thereafter, we evaluated the importance of the piece of information: does the issue constrain or enable the use of CCF among the forest owners.

\section{Forest Owners}

\section{Visits and Interviews}

The interviews with individual private forest owners were conducted in years 20182020. As we wanted to conduct a qualitative analysis, we did not expect to achieve a representative sample but a sample with high variety. We interviewed 18 forest owners. In the study region, forest owners have no obligation to define their management strategies. Therefore, it was quite difficult for us to find CCF practitioners. Initially, we investigated, using the national forest register, the official cutting notices where the use of selection cuttings was mentioned. However, many owners harvest such small amounts of timber that they do not have to declare it (up to $20 \mathrm{~m}^{3} / \mathrm{y}$ per estate). We thus broadened the search via forestry cooperatives and asked for advice from forestry and nature protection experts as well as other respondents. Most of the owners had relatively small forests and managed them as a side activity. Large forest owners in general are rare in Estonia: 1\% of individual forest owners own more forest land than 50 ha (Raudsaar et al. 2018). To include some with large properties or with well-functioning management models, we also included an owner with CCF demonstration farm from Latvia (about $1000 \mathrm{ha}$ ). To understand how the forestry regimes in Latvia and Estonia differ, we consulted with a leading person of the network of CCF demonstration forests (Jānis Rozītis from WWF Latvia) but did not find any differences that would strongly influence the owners' practices. Thus, the Latvian owner was analysed as others.

Together with the owners, we visited their forest and carried out a semi-structured interview along with the forest walk (in one case, we got the answers by e-mail, and we visited the forest independently). Thanks to the on-spot observation, we had an opportunity to perceive the outcomes of the forest management practices directly in addition to the memories and interpretation of the interview partner (Daymon and Holloway, 2002). During the interview we discussed issues that helped to clarify their social embedding and the connections to the rule regime of forestry (Appendix 1). 


\section{Characterising the Owners and Analysing Their Niche Experimentation Opportunities}

All interviews were recorded, transcribed verbatim and thematically coded according to the research focus, questions, and data. The coding was performed using a qualitative software program MAXQDA 11. Firstly, we used deductive qualitative content analysis (see Ezzy 2002), i.e., in the formation of analytic codes, we emanated from theoretical and empirical premises. Secondly, we carried out inductive coding, i.e., we complemented research categories with codes that emerged from the research material (such as unexpected responses). To ensure that our sample of forest owners is diverse, we began our qualitative content analysis from characterisation of the owners following main six categories (Appendix 2). Economic and ecological incentives that contradict in $\mathrm{CCF}$ are often used to group forest owners in research (Ficko et al. 2019, Blanco et al. 2015). In addition to these categories, we coded networking activities because the way actors obey formal rules and normative prescriptions depends on their social embedding in regulatory structures and social networks (Geels 2020). For social networks, we distinguished between neighbourhood networks and ideological networks (CCF network). We also distinguished owner's relations with the forestry sector (traditional forestry education, working experience in forestry sector, membership in forestry association).

To characterise our interviewees according to forest owners' values and motivations (Ficko et al. 2019) and according to skills and networks significant in MLP approach, we analysed the existence of codes in a particular category and their variability within that category.

Next, we described (i) how forest owners perceive their opportunities in the context of their actions: their judgments on regulative and normative rules, and their use of cognitive rules, and (ii) respective potential for inducing niche changes.

\section{Synthesising the Possibilities to Foster Experimental Niche}

Finally, we synthesised the regime and owners' analyses to search for possibilities to foster experimentation among the owners and thus also possibilities for CCF niche development within the rule regime of forestry. We (i) revised the regime deficiencies in the sense of support for CCF and (ii) revised the owners' analysis by asking what kind of support could enhance their CCF activities and bring in new practitioners. As actors' networks take part in the formation and fastening of change in MLP approach, we propose policy solutions that help to tighten already existing embryonic networks of the owners. Id est, we use forest owners' particular social embeddings and experiences with changing the rules as an analytical tool to hypothesise how specific policies can evoke CCF management approaches and respective outcomes. 


\section{Results}

\section{CCF Perspectives in the Socio-technical Regime of Forestry in Estonia}

\section{Socio-cultural Sub-regime}

The historical roots and experiences of CCF in Estonia that present-day experimenters could rely on are weak (Table 1). Clear-cutting-oriented system has been the primary management system in Estonian state forests since the end of the 19th century; in private forests, the methods varied (Meikar 2001). In the first period of Estonian independence, from 1918 to 1940, Alfred Möller's (1922) idea of 'Dauerwald' inspired Estonian forest scholars to compile written instructions (Schabak

Table 1 Elements of forestry regime that influence the development of a CCF niche in Estonia. The elements represent the five sub-regimes (Fig. 1) and were delineated during document analysis

\begin{tabular}{|c|c|c|}
\hline Sub-regime & Regime element & Description \\
\hline \multirow{3}{*}{$\begin{array}{l}\text { Socio-cultural } \\
\text { formations }\end{array}$} & Advocacy for CCF & Weak in the forestry sector but strongly articulated outside \\
\hline & Shared experience & $\begin{array}{l}\text { Forest owners' circles lack practical CCF examples to rely } \\
\text { on. }\end{array}$ \\
\hline & Public support & $\begin{array}{l}\text { Public opinion and small forest owners favour nature- } \\
\text { friendly forest management. }\end{array}$ \\
\hline \multirow[t]{4}{*}{$\begin{array}{l}\text { Science and } \\
\text { education }\end{array}$} & $\begin{array}{l}\text { Long-term monitoring } \\
\text { of CCF plots }\end{array}$ & Lacking. \\
\hline & Scientific research & Just emerging. \\
\hline & Educational materials & $\begin{array}{l}\text { CCF is introduced with a chapter in textbooks and manu- } \\
\text { als; the first CCF handbook was published in } 2020 \text {. }\end{array}$ \\
\hline & Demonstration areas & The first was created in 2019. \\
\hline \multirow[t]{4}{*}{$\begin{array}{l}\text { Policies and sup- } \\
\text { port system }\end{array}$} & $\begin{array}{l}\text { Official instructions } \\
\text { for forest inventory }\end{array}$ & $\begin{array}{l}\text { Not optimised for CCF needs, e.g., the diameter distribu- } \\
\text { tion is not demanded. }\end{array}$ \\
\hline & Subsidy system & No support for CCF-specific activities. \\
\hline & Restrictions & $\begin{array}{l}\text { In general, not impeding reasonable CCF. Selective cut- } \\
\text { tings in forests, where the first layer is mature, is allowed, } \\
\text { but the wording of the law allows selective felling to be } \\
\text { used for intensive logging. }\end{array}$ \\
\hline & Support system & $\begin{array}{l}\text { Forestry associations are not motivated to support CCF. } \\
\text { CCF association was established in } 2018 \text {. }\end{array}$ \\
\hline \multirow[t]{2}{*}{$\begin{array}{l}\text { Technologies in } \\
\text { forestry and tim- } \\
\text { ber processing }\end{array}$} & Machinery & $\begin{array}{l}\text { The competitive advantage of chainsaw workers next to } \\
\text { big harvesters and forwarders is low; smaller machinery } \\
\text { has found little use until now. }\end{array}$ \\
\hline & $\begin{array}{l}\text { Valuing of special } \\
\text { CCF timber }\end{array}$ & $\begin{array}{l}\text { Used non-industrially, a lack of business clusters and } \\
\text { networks. }\end{array}$ \\
\hline \multirow[t]{4}{*}{$\begin{array}{l}\text { End-users and } \\
\text { beneficiaries }\end{array}$} & $\begin{array}{l}\text { The market for non- } \\
\text { timber products }\end{array}$ & Fragmentary. \\
\hline & Tourism & $\begin{array}{l}\text { Extensive forests are a considerable motive for tourists; } \\
\text { the share of tourism in Estonian GDP is high. }\end{array}$ \\
\hline & $\begin{array}{l}\text { Nature protection } \\
\text { administration }\end{array}$ & $\begin{array}{l}\text { Selection cuttings are underused in limited-management } \\
\text { zones: often, clear-cutting is used. }\end{array}$ \\
\hline & Local communities & $\begin{array}{l}\text { CCF is expected to alleviate local conflicts over the clear- } \\
\text { cutting of forests. }\end{array}$ \\
\hline
\end{tabular}


1931, Daniel 1936) for private forests. At that time, private forests formed ca 50\% of Estonian forests (Meikar and Etverk 2000). The development of CCF practices was cut short by the Soviet period (1949-1992) when the land was nationalised, and selection cuttings were mainly restricted to protected forests (some collective farms probably also used selection and selective cuttings) (Meikar 2001).

In the $1990 \mathrm{~s}$, selection cuttings decreased even further. Land properties were returned to their former owners or their heritors, many having no experience with forest management. In 1997-1999 selection cuttings formed an average of $4.1 \%$ of the total volume harvested from private forests; in 2016-2018, that proportion was only $0.02 \%$ (Raudsaar et al. 2018). Those estimates, however, are based on forest notices that do not entirely reflect actual management. Forestry experts tend to repeat that CCF is not practical in Estonia due to present-day forest structure as most of the forests are even-aged (cognitive rule, Kiisel et al. 2018). Actually, most productive commercial forests are mixed (incl. several relatively shade-tolerant species) and uneven-aged (Adermann 2012, Lõhmus and Kraut 2010): a result of natural regeneration rather than an intentional aim of mixed uneven-aged structure. Thus, the suitability of forest structure for CCF varies stand-by-stand and creates different baselines for the owners.

The popularity of CCF is rising somewhat due to changes in the socio-technical landscape - narratives of ecological degradation and various ecosystem services become more and more apparent in social norms. For example, in 2001, Estonian forest owners prioritised timber value over other forest values, but in 2019 the importance of nature protection and human health was considered more important than the economic value of timber (Turu-uuringute AS 2019). The annual clear-cut area has increased three times since the year 2000 (Raudsaar et al. 2018), has become well observable on the landscape, and has caused resentment (Kiisel et al. 2018, Turuuuringute AS 2018, see also ch. 3.1.5.)

\section{Science and Education Sub-regime}

The profitability of timber production in CCF and clear-cutting-oriented technology has not been compared scientifically in Estonia, and there are no long-term monitoring plots, although attempts have been made to create these in history (e.g., Örd 2000) and recently (ETIS 2020a). Although CCF has been shown to be economically reasonable in neighbouring southern Finland (Pukkala et al. 2012, Juutinen et al. 2018), local models that include various influential factors are needed to call for investment in CCF. Modelling would need a detailed description of diameter distribution and spatial variations in stand structures, but the degree of detail within the official instructions for forest inventory (Instruction for forest inventory 2018) are not optimal enough for CCF and, therefore, impede the evolution of the analytical concepts of CCF (cognitive rules). Also, our respondents did not follow the fundamental CCF-specific quantitative planning methods, e.g., no respondents had done diameter distribution measurements.

In recent years, the scientific interest in CCF has increased. A sign that normative rules within the science sub-regime may begin to change is that during the forestry development planning process, the research on and usage of CCF was suggested by 
the Environmental Board, environmentalists, nature tourism entrepreneurs, humanitarian and social researchers, but notably not the Private Forest Union (Ministry of the Environment 2018). Now the first experiment for studying carbon balance and the economy of selection cutting is underway (Environmental Board 2021, ETIS 2020b).

In educational material, similarly, the guidance for CCF is scarce (e.g., Aitsam 2012, Laas et al. 2011) or recent in textbooks (Remm et al. 2020); the first demonstration area was created in 2019 (ELF 2019). Notably, none of our respondents considered formal forestry education as a source of CCF specific knowledge. Instead, they relied on foreign sources. The lack of CCF experts is one of the probable causes for the dominance of clear-cutting-oriented management services and consultancy in owner associations (and vice-versa: the incumbent regime actors have not had the interest to develop CCF expertise). At the same time, the forest owners, in general, have not explicitly asked for CCF advice from associations (Org 2018) - lack of such cognitive rules, i.e., thinking frameworks for $\mathrm{CCF}$, does not trouble them.

\section{Policies and Support System Sub-regime}

Here we found numerous restricting or undeveloped regulative rules for $\mathrm{CCF}$. At the end of the $1990 \mathrm{~s}$ and the beginning of the $2000 \mathrm{~s}$, CCF was partly or wholly forbidden by governmental forest authorities who wanted to prevent the use of selective cuttings to eliminate the most valuable timber at the expense of timber production perspective (Etverk 2005). Nevertheless, it continued among forest owners (among the 'hobby owners', 'farm forest owners', etc.) as a small amount of timber is allowed to be removed without submitting a forest notice under the guise of selection cuttings (until $200915 \mathrm{~m}^{3} / \mathrm{y}$ per estate, since then 20 [Forest Act 2007 and 2009]).

From 2008 to 2017, a forest owner could apply selection cuttings in certain site types in Estonia. In 2017, restrictions for site types, the maximum amount permitted to cut within a year, minimum residual crop density and basal area of the first layer were removed. Only a rather low minimum basal area for the whole stand and a requirement that the first layer should be mature remained. The age limit is set to prevent the over-harvesting of young forests; however, for the owners who want to transform young even-aged stands to uneven-aged stands, it is an obstacle: "But what is the concern in my forest management, I do not say that it should be changed by law but may-be when the society is more developed, it would be reasonable. Continuous cover forestry, as I do it, is limited because we cannot do gap cuttings in premature stands" (O16, an economically oriented owner). CCF practitioners may also meet difficulties when the average age of the first layer in uneven stands does not exceed the rotation age, but some trees are mature.

The subsidy system of forestry includes support for soil scarification, plantation, cleaning, and pre-commercial thinning (Requirements for applying and providing subsidies in private forestry 2021, Investment support for forest development and forest health 2018), but not for any of the activities of CCF such as continuous, labour-intensive (often manual) harvesting and marking the trees before cutting. Also, in limited-management zones where clear-cutting is forbidden, CCF is not specifically endorsed. Limited-management zone means that (in total $2900 \mathrm{~km}^{2}$; Raudsaar et al. 2018) forest management is allowed, but various restrictions may be set to 
protect biodiversity, recreational values, water, soil, or landscapes. The subsidies in the Natura areas are for tolerating clear-cutting restrictions, but not specifically for CCF activity. Forests that are in limited-management zones but outside Natura areas are not subsidised. Some of the subsidies are only available through associations, whereas the associations must have at least 200 members (Requirements for applying and providing subsidies in private forestry 2021), and they are directed toward intensive rotation forestry as the minimum amount of timber sold and area managed with rotation forestry methods are set. Hence CCF-aiming owners and consultants face a dilemma: the consultants are demotivated to suggest small-scale selection cutting. Even if the consultant suggests selection cutting, losses for the owner are highly probable. The last is because the contractor may take the best trees (thus decreasing the stand quality) and take more than optimal for CCF (as the minimum residual basal area is low).

As only a minority of forest owners belong to associations, it is more likely that forest owners who incline towards uncommon forestry practices look for representation elsewhere. Among those 11 interviewed owners who are or have been members of an association, no one has got CCF-specific support from associations. To serve their interests, the Continuous Cover Forest Association was established in 2018 (hereby having a significant effect on the development of cognitive rules and signalling the official establishment of the concept in Estonia). Therefore, we can speak of some bottom-up CCF niche development.

\section{Technologies in Forestry and Timber Processing}

The spread of CCF is also limited by machinery (Table 1), considering that certain types of machines (e.g., small harvesters) are more needed in CCF than in rotation forestry, a deficit of such machines could make clear-cutting service more easily accessible than selection cutting. This situation is changing, though. For example, after the big harvesters (in Estonia, there are ca. 500 of them), innovative small harvesters are entering the market (associations have acquired 5 of these) to ease the lack of chainsaw workers (Alvela 2019, Kosenkranius 2016). Our respondents predominantly used their own or their neighbours' old tractors (that they considered perfectly appropriate) or ordered the service. In the last case, both small and large harvesters were used. No experiences with CCF-specialised forest management service companies were mentioned. We can say that some cognitive rules are changing (such as that felling needs big harvesters), but norms among companies not yet notably.

One of the options to increase the income from CCF is to canalise the high-quality timber to special value chains. However, the timber from CCF receives no special treatment on the general timber market. The interviews with forest owners revealed that special valuing of high-quality timber of slowly grown trees or from uncommon species depends on the personal contacts of forest owners or ability to process the timber by themselves.

Slowly grown, dense wood, curvy, or very large boles, trees from uncommon species and with colourful fungal infections are processed in smaller quantities than is the capacity of forest owners to produce these. Although this kind of raw material may be extracted from CCF more efficiently than from even-aged stands and is also 
used in the Estonian industry on a small scale (Tarn 2018), the costs of logistics and a lack of knowledge discourages forest owners' associations. There is also a lack of business clusters, networks and information technology that would connect owners to mediating and processing enterprises.

\section{End-users' and Beneficiaries' Sub-regime}

CCF is better than rotation forestry in terms of certain non-timber forest products (NTFP): bilberries and possibly edible mushrooms (Tomao et al. 2017, Peura et al. 2018). Other NTFP may be favoured by rotation forestry, like cowberries (Peura et al. 2018, which, though, are cheaper than bilberries; Miina et al. 2016). In Estonia, only some forest produce belongs exclusively to the owner, e.g., tree-specific material like willow bark, wicker rods, pine shoots, resin, as well as tree saps. The right to walk in forests and pick berries and mushrooms is granted to everyone, i.e., maintaining the yield in one location and on their own land is not essential for gathering berries and mushrooms. However, NTFP gatherers in Estonia usually have long-term sites in forests not belonging to them and are strongly disturbed by clear-cuttings and intensive forestry (Remm et al. 2018). Thus, the market for NTFP could create an external demand for CCF. NTFP are consumed nationally and exported, but also imported (Statistics Estonia 2019). Among forest owners, marketing opportunities and skills seem to be even more detrimental for gaining profit from NTFP than forest productivity. In our sample, only an owner living in a most touristic place marketed NTFP: sold souvenirs with tar through a local handicraft shop.

The demand for CCF has risen among local communities and tourists. From the beginning of 2018 until the end of 2020, at least 28 protests against clear-cutting in forests close to settlements or hiking trails have been reflected in local media, versus 9 in 2015-2017 (change in normative rules) ${ }^{2}$. These protests are a part of a new public dispute over forests, the so-called forest war (Vihma and Toikka 2021). Notably, the conflict is not about (any type of) forest management: local people have seen management with selection (or even shelterwood) cuttings as a solution in more than $3 / 4$ of those protests. CCF has also been proposed as a solution in public discussions (e.g. Laik 2018).

There are political struggles also between the forestry and tourism sectors, as recreational forest users and tourists resent clear-cuts. The conflicts have been risen because of clear-cuttings around tourism farms, natural sightseeings, and in protected areas as well as the general extent of clear-cutting that impacts the image of Estonia (Ruukel 2020). Distressed tourist companies have written public letters to parliament and the ministers requiring more sustainable forest management practices and inclusion of the tourism sector to the institutions that develop the forest policy (Ruukel and Rähni 2017, ETFL 2018). Nature tourism has been indeed an important sector. In summer, 37\% of foreign tourists visit nature on their own (Statistics Estonia 2018). The direct share of tourism in Estonian GDP was 5.5\%, with indirect effects amounting to $7.9 \%$ in 2015 (EAS 2019, Statistics Estonia 2019). At the same time, the direct

\footnotetext{
${ }^{2}$ Google search in 25.08.2020 with phrases home forest clear-cutting, locals continuous cover forest, locals against forest cutting, and clear-cutting locals, all in Estonian.
} 
share of GDP for forestry was $1.1 \%$, while the wood processing industry amounted to $2.7 \%$, and the paper and furniture industry $1.4 \%$ (Raudsaar et al. 2017). The COVID19 crisis impeded the foreign tourists, but visiting nature increased much (Viiron 2020, see also, e.g., Venter et al. 2020).

In nature conservation, finding an ecologically, legislatively, and economically suitable silvicultural approach for limited-management zones is seen as a research priority by stakeholders (Lõhmus et al. 2019). Furthermore, the first project to demonstrate CCF's potential in flying squirrel's habitats has been initiated (Environmental Board 2021).

We can conclude that in the rule regime of forestry, a tiny niche for CCF exists, and support for $\mathrm{CCF}$ is faster growing among parties that lie outside of the forestry sector and suffer from the side-effects of its activity but lack direct tools to change the sector. The regime shift is supported by considerable market demand, namely from the tourism sector. This signals a minor co-evolution between sub-regimes and major landscape-level changes that affect social expectations to forestry. Irrespective of the changes in normative rules, the cognitive (analytical concepts that give sense to CCF) and regulative rules remain rigid.

\section{The Owners}

The forest owners we interviewed were not like-minded and not similarly acting people. They came to CCF practice via different routes, and each person interprets the concept differently. Not one participant had experience with CCF pre-dating the early $1990 \mathrm{~s}$. Some had been active in the forestry sector since Soviet times, but at that time, they relied mainly on the instructions and plans given to them by forestry institutions. The size of the biggest property where only CCF methods were applied was $50 \mathrm{ha}$; the respondents with larger properties than this had used clear-cutting in some parts of the forest. We argue that pure CCF practitioners with larger properties currently are very rare in our region-despite many efforts, we did not find any examples, although we found additional small-scale natural economy managers whom we did not interview because we aimed for a diverse sample covering various profiles. So, we can conclude that CCF in Estonia predominantly appears in the form of small-scale forestry.

\section{The Reasoning of Avoiding Clear-cutting}

Several respondents combined clear-cutting with selection cuttings for economic benefits. Those who valued the ecological aspects of the forest most tended to avoid clear-cuts. The reasons for preferring CCF to clear-cutting were quite diverse and encompassed mainly individual normative motives, for example earning income continuously, getting wood material, avoiding reforestation costs, the wish to achieve higher timber quality, preferences for landscape aesthetics, awe-inspiring feelings towards the forest, the preservation of biodiversity, but also cognitive (defining the forest as a part of one's home) rules. Next to individual factors, the underlying reason for clear-cutting by $\mathrm{CCF}$ followers could be seen within existing stand structures and the lack of preceding, uneven-aged targets in management practices (cognitive 
rules). E.g., in even-aged (over)mature stands of short-lived species (e.g., grey alder), even some keen CCF followers had carried out clear-cuttings. The only regulative rule (local clear-cutting restrictions) that impose $\mathrm{CCF}$ do not originate from forestry policy sub-regime but from end-users' regime (nature protection). In four land ownerships of our sample, clear-cutting was prohibited on at least $20 \%$ of the area, but selection cutting was allowed.

\section{Characteristics and Social Embeddings of Forest Owners Practicing CCF}

The CCF practitioners' contribution to niche experimentation varies according to their characteristics and social embeddings (Table 2; Fig. 3).

For several forest owners the forest serves as the main source of income (in literature also economically interested, with economic efficiency motivations, etc.). They invested in machines, bought extra forest land as an investment. Some pos-

Table 2 Number of respondents who had the studied characteristics (code categories, cf. Appendix 2) at low, medium, and high level. Note that the table describes the sample, but not necessarily the forest owners in CCF niche in general. The relations to forest associations: a-absent, $\mathrm{p}$ - pragmatic, $\mathrm{s}$ - selective, d-dependent, i-ideologically incompatible

\begin{tabular}{llll}
\hline Characteristic & High & Medium & Low \\
\hline Forest as economic investment & 4 & 7 & 7 \\
Valuation of ecological aspects & 3 & 4 & 11 \\
Skills in forest management & 10 & 3 & 5 \\
Networking policymakers and colleagues in CCF & 5 & 6 & 7 \\
Networking with neighbourhood & 4 & 6 & 8 \\
Cooperation with incumbent associations & $7 \mathrm{a}, 3 \mathrm{p}, 4 \mathrm{~s}, 1 \mathrm{~d}, 3 \mathrm{i}$ & \\
Median, min, max area of the forest property (ha) & $32,9,1000$ & \\
Range of ages (y) & $30-77$ & & \\
Number of respondents/females & $18 / 3$ & \\
\hline
\end{tabular}

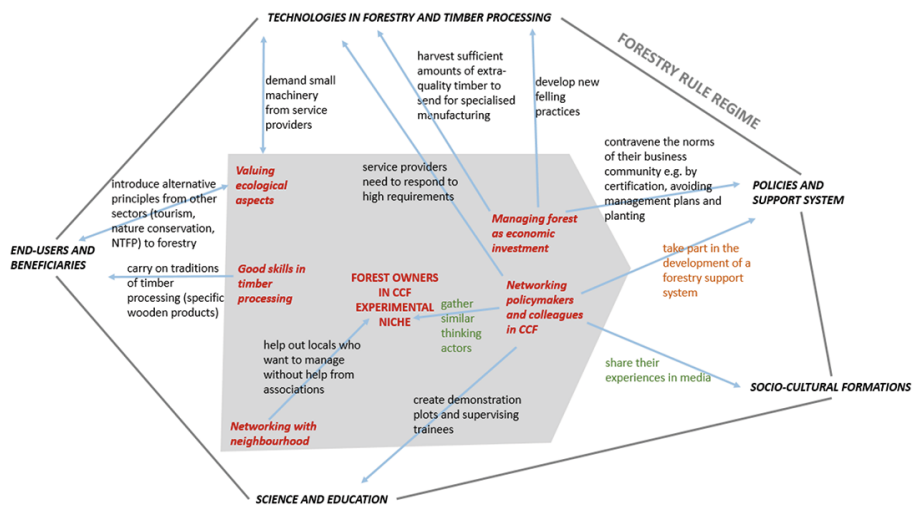

Fig. 3 Contribution of the forest owners to CCF experimental niche formation. CCF - continuous cover forestry, NTFP — non-timber forest products. Black — cognitive, green — normative, brown-regulative rules 
sess excellent knowledge of nature and strive to their vision of the ideal forest (in literature ecologists, with environmental goals, etc.). The owners differed not just by their motives but also by the scope and the mastery of their skills. Due to variable and excellent skills, some owners can operate practically independently (especially those who have their own machines for forest work) - they know how to plan their forest management, order management services, reprocess wood, educate trainees, etc. The skills were embedded in the actors' networks of the owners. Those who lacked the skills had to rely on forest associations or forest management companies (and vice versa - the help from these counterparts may impede the development of personal skills of the owner). Some had personal contacts with forestry professionals that substituted the need for advice from the official support system. Some use to contribute to the relations with their local forest neighbours and ask for their help (and vice versa).

Those who network with ideological communities prefer to ask for advice from their networks or to follow its specific agenda. They also share their experiences and discuss forestry policies with a network of sympathisers from forestry, culture, or ecology. Although such owners may also work along with forest association and forest management companies, they want to stick to their lifestyle beliefs.

Some owners are tightly connected to regional communities, i.e., their inherited land, household and neighbourhood (in literature also farmer forest owners, classic forest owners, etc.). The natural, reciprocal economic-exchange relations of the rural community help find the necessary workforce and simpler forestry machines.

Depending on the owners' convictions, the relations to forest association can be absent, pragmatic, selective, dependent, or even ideologically incompatible. In our sample only some owners found that mainstream forest association's support fits the needs of applying CCF.

\section{Owners' Experiences with Changing the Rules for CCF}

Forest owners bend mostly cognitive rules: concepts and frameworks of doing things (Fig. 3). Many tend to modify forestry methods according to their aspirations (for some forest value) and skills accommodated in their social embedding.

"I have invented a forest management system that I'll apply when people realise that forestry should be reappraised and timber is a secondary use of the forest and a very, very little important one. If that will be understood, then this forest management method will spread.“( $\mathrm{O} 5$, high ecological aspirations).

Their personal skills and resources play a part in experimental activities. Those who lack management skills or machinery must rely on forest associations' consultant or must find a trustworthy service provider. This impedes experimenting, as according to the experience of our interviewees, an owner needs a lot of self-confidence to demand, e.g., smaller machinery or preservation of natural regeneration during clearcutting from service providers or forestry consultants. Usually, the selective cuttings were made by the owners themselves as they trusted their own skills more. Those who experiment with the silvicultural approach are independent due to their skills and access to machinery, but the inspiration for changes originates from their specific ideological networks. These (developing) networks help to set new perspectives for 
silvicultural practices. The owners who do not connect to scientific or worldviewbased communities, who lack personal skills, who can rely only on their neighbourhood community or forest association, do not feel the need for experimentation.

The business networks of forest owners for selling their forest products (except bigger quantities of timber that originate from clear-cuts) go just a little further than their community. Due to larger quantities of higher quality timber and respective business contacts, some owners can send it to special manufacturing, but these business acts are rare. Some owners can produce wooden products themselves, yet they cannot build business networks to ensure continuous demand. NTFP advantages are used only for personal purposes. Therefore, the use of advantages of CCF relies much on the development of the technologies and timber processing sub-regime.

Owners often think along or act according to the rising expectations of sociocultural (public discussion on forest use) and end-users' sub-regime (tourism development needs, NTFP potential), observe or look for scientific information (science and education sub-regime). Although they are attentive to the policies' and support system sub-regime, they ignored or adapted incumbent regime forestry principles to their own needs, but in general, they did not pay much attention to those.

"For me, the management plan is a good thing to check the age, height, and volume of the stands, but in general, I have ignored the management suggestions. [...] I have to admit: when you start with CCF, first of all, ignore the management plan." (O12, a skilled owner).

An exception here were the self-conscious forest owners who take part in CCF network activities and in public discussion over forestry politics. Irrespective of their forestry education and work experience, they are disappointed in forestry policy and the support system.

"They [people in association] made unpleasant statements: we should cut more, and the rotation ages should be lowered. I left the association before I even got any subsidies. I cannot be a member of an organisation that makes such statements." (O4, member of ideological community).

Therefore, they take steps to shape the regulative rules of forestry: these owners have a say in the media and discuss forestry with policymakers and other sub-regime representatives, but also run in elections. They gather opposition to present forestry policy-making (normative rule), i.e. serve as spokespersons and advisors for the people interested in CCF.

\section{The Support for CCF Practitioners}

At present, the owners' ability to form an experimental niche is impeded from the owners' side by low networking level and the small number of practitioners (normbuilding); from the forestry sector lack of support (regulation formation). Emanating from the weaknesses of the forestry regime and the aims of interviewed forest owners, opportunities to foster the regime emerge (Table 3). Strategic niche development can increase the number of CCF practitioners among forest owners, but it is hard to predict whether the solving of present shortcomings will foster the CCF niche development. 
Table 3 The opportunities to foster CCF niche according to sub-regimes

\begin{tabular}{|c|c|}
\hline $\begin{array}{l}\text { Sub-regimes of } \\
\text { forestry }\end{array}$ & Opportunities to foster CCF practices \\
\hline $\begin{array}{l}\text { Policies and support } \\
\text { system }\end{array}$ & $\begin{array}{l}\text { (i) Subsidies that would cover higher costs of selective cutting (regulative rules); } \\
\text { (ii) Restructuring the financing of forest associations to motivate them for CCF } \\
\text { (regulative rules); } \\
\text { (iii) Support to CCF community networking and expert organisation formation } \\
\text { (normative rules) }\end{array}$ \\
\hline $\begin{array}{l}\text { Technologies in } \\
\text { forestry and timber } \\
\text { processing }\end{array}$ & $\begin{array}{l}\text { (i) Training of forest holding and management companies, recognition for using } \\
\text { CCF (cognitive and normative rules); } \\
\text { (ii) Initiation of business models for special timber assortments (cognitive rules); } \\
\text { (iii) Preferences to smaller forest machines in financial support mechanisms } \\
\text { (regulative rules); }\end{array}$ \\
\hline $\begin{array}{l}\text { Science and } \\
\text { education }\end{array}$ & $\begin{array}{l}\text { (i) Creation of public demonstration plots and funding of respective research } \\
\text { projects (cognitive rules) }\end{array}$ \\
\hline $\begin{array}{l}\text { End-users and } \\
\text { beneficiaries }\end{array}$ & $\begin{array}{l}\text { (i) Initiation of mixed and networked rural business models in forestry (like } \\
\text { building boats or processing NTFP and selling those via short value chains) } \\
\text { (cognitive rules); } \\
\text { (ii) Financial support to the owners according to the improvement of biodiver- } \\
\text { sity indicators of their forest (regulative rules); } \\
\text { (iii) Regulations to enhance CCF in the key areas of nature tourism (regulative } \\
\text { rules) }\end{array}$ \\
\hline
\end{tabular}

However, it is necessary to accommodate CCF expertise in the forestry support system to change its internal norms and regulate the use of CCF in practice to aim its advantages instead of misuse. Instead of random providers of logging services, forest owners practising CCF need long-term and trustworthy partners among holding and management companies who possess respective skills and suitable machinery. For this, scientifically grounded experience is needed. Already existent but weak actor networks that cross the forestry sector (regional planning, technology development, tourism, recreation services) need to develop to empower those owners and their specific cooperation chains.

\section{Discussion}

Our overview, although broad in scope, illustrates how both forest owners applying CCF and forestry regime can enhance the CCF experimental niche. Our analysis indicates that wider adoption of uneven-aged forest management is hindered due to several lock-in mechanisms in the forestry rule regime. The result is similar to the conclusions by Helliwell and Wilson (2012), who delineated the barriers for CCF in the UK: (i) a lack of consistent, long-term forest policy and financial support, (ii) the lack of training and expertise, (iii) unthinned stands that are difficult to transform, (iv) market distortion by grants that are not favourable for CCF, (v) a lack of agreed methods of inventory, and (vi) unclear terminology. Our analysis points out some additional barriers: the insufficient development of economic value chains for special timber assortments and too little cooperation with sectors that would benefit from CCF (regional planning, tourism, nature protection, i.e., so-called end-users' subregime, but also technology and science sub-regimes). 
We found that social processes of strategic experimental niche formation for CCF are developing. The changes in the forestry regime have taken place mostly as changes in socio-cultural evaluations, but tiny pro-CCF modifications in science and technology sub-regimes are also happening (changes in concepts, frameworks). On the other side, forest owners contribute mostly with how-to-do knowledge (cognitive rules). However, their potential to form an experimental niche for CCF relies only on personal motives and random factors such as stand structure and limited management zones. Therefore, the formation of an experimental niche of CCF depends on the changes in policy sub-regime, i.e., changes in regulations that create demand for CCF within forest owners' specific social embeddings. The policymakers should not let themselves be confused by the size of the CCF forest owners present segment. The owners with lower potential for active niche development are actually numerous and, if provided, could demand CCF-specific silvicultural services for due to rising ecological anxiety even among forest owners (Turu-uuringute AS 2019). Moreover, city inhabitants of wealthier societies tend to prefer CCF (Juutinen et al. 2020). The question is whether existing changes in socio-cultural sub-regime and CCF practitioners' niche will evoke necessary transition in policy-regime.

Geels's (2014) study shows that incumbent regime actors use instrumental, discursive, material, and institutional forms of power to resist pressure and the critical examination of the regime. This is also true for this Estonian case of CCF. However, the resistance does not reverse the need for learning, risk assessment, and corresponding policy preparations. For example, Axelsson and Angelstam (2011) found that even the forestry agencies who usually consider CCF uneconomical admit that it has advantages in ecological and socio-cultural dimensions. According to the MLP approach, transitions can be accelerated by actively phasing out existing systems, for example, decreasing subsidies to intensive forestry (van Beers and van den Bergh 2001), but redevelopment plans for incumbent actors would reduce the likelihood of resistance (Geels et al. 2017).

The decisive push for the forestry regime to start planning for the experimental niche of CCF may originate from the so-called landscape level of socio-technical transitions (Geels 2004), i.e. tremendous global challenges that do not originate from the responsibility area of a particular rule regime such as forestry. These kinds of challenges necessitate revival processes in regime rules, as they are usually incompatible with the needs to cope with the challenge. E.g., the need to respond to the climate challenge, especially as this is also urged by political agreements such as the European Green Deal and its Biodiversity Strategy.

These kinds of challenges also push other rule regimes of society that are in dialogue with the forestry regime, for example, the financial sector. Until recent times, only private forest owners counted on their forest as a warranty for their retirement insurance. The interest in CCF investments is rising among asset managers of retirement funds that have to respond to a growing demand for environmentally responsible services (see, e.g. McMahon et al. 2016). The concepts such as sustainable finance have entered the policy arena (Ramiah and Gregoriou 2016), and this will also have a long-term effect on forest investments. We propose that macro changes in society and the need to respond to respective transformations in other rule regimes 
beyond forestry will enforce necessary changes in forestry policies for the formation of CCF experimental niche.

\section{Conclusions}

Our analysis shows that there is a public demand for CCF (normative rules) that indicates a need for strategic CCF niche development. Yet the current forestry support system and regime in general do not facilitate the employment of CCF advantages, and sometimes it even impedes it by inconsistent regulations (regulative rules) and lack of officially adopted concepts and measures (cognitive rules). Also, the owners' ability to act as an experimental niche is hindered by low networking and a small number of practitioners. However, the experiences of present niche experimenters are useful in the development process of CCF.

Based on the shortcomings of the forestry regime and experimental niche we conclude that several opportunities exist to develop an experimental niche of forest owners practicing CCF. In the forestry sector (policy and regulations regime), the forest owners who adopt CCF can help share their felling technique and machinery improvements; owners who criticise the incumbent regime can help in policy development. There is also a potential to foster cooperation between forestry and other sectors such as tourism, nature protection, and regional planning to support non-timber outcomes of CCF and strengthen ties between forest owners and social stakeholders.

As we did not interview persons who are not engaged in CCF, the description presents only a partial view of limitations to encouraging more practitioners into CCF. We suggest further studies (and preferably intervention studies) on owners who could adopt CCF if certain lock-in mechanisms were removed.

\section{Appendix 1}

The issues discussed during the interviews with forest owners and assessed during the forest walk

\begin{tabular}{ll}
\hline The issues discussed during the interviews & $\begin{array}{l}\text { Observed } \\
\text { during } \\
\text { the walk }\end{array}$ \\
\hline
\end{tabular}

The forest 'owner's relationship with the forest and the process of becoming a forest owner

The principles for forest management that the owner follows

The peculiarities of the forest's ecological, cultural and economic values

The expectations of the owner for the future of the forest

Activities in the forest and the involvement of family in the process

Relations with the neighbourhood and community near the forest property

The use of timber and non-timber forest products (NTFP) and the reprocessing of those products 
The issues discussed during the interviews

Observed

during

the walk

Profits from the forest and what proportion of the family income they constitute

Outsourcing of forest management

The relationship with forestry associations and the use of respective services

Types of education in forestry (self-education included)

The circles of information about forestry (e.g. consultation, media, and experts)

The possession and use of technical equipment

\section{Appendix 2}

The six categories and respective codes for profiling the forest owners

\begin{tabular}{|c|c|}
\hline $\begin{array}{l}\text { The category of } \\
\text { analysis }\end{array}$ & Respective codes \\
\hline \multirow{5}{*}{$\begin{array}{l}\text { Forest as economic } \\
\text { investment }\end{array}$} & * processes the wood on its own, by their own means \\
\hline & * have hired workers to manage the forest \\
\hline & $\begin{array}{l}* \text { bought some forest by their own means (e.g. in addition to regained land by } \\
\text { privatisation) }\end{array}$ \\
\hline & $\begin{array}{l}\text { * has bought some kind of machines by their own means (in addition to those } \\
\text { gained in the process of privatisation) }\end{array}$ \\
\hline & * the owners have sold timber to the open market \\
\hline \multirow[t]{5}{*}{$\begin{array}{l}\text { Evaluation of eco- } \\
\text { logical aspects }\end{array}$} & $\begin{array}{l}1 \text {-recognise some common species like strawberries, but the focus of their } \\
\text { attention is on the appearance or beauty of the landscape }\end{array}$ \\
\hline & $\begin{array}{l}2 \text { - recognise forest tree species with use-value and species that indicate soil } \\
\text { types }\end{array}$ \\
\hline & $\begin{array}{l}3 \text { - know well habitats and their indicator species, recognises the activity of for- } \\
\text { est animals, but the focus of the owner's attention is rather economical }\end{array}$ \\
\hline & $\begin{array}{l}4 \text { differentiate between many species and habitats also for their own sake not } \\
\text { for just their economic value, likes to observe nature and cultural heritage }\end{array}$ \\
\hline & $\begin{array}{l}5-\text { know nature and its processes well (at the scientific level), recognise species } \\
\text { that have no use in people lives, evaluate nature according to ecological values }\end{array}$ \\
\hline \multirow[t]{11}{*}{$\begin{array}{l}\text { Skills in forest } \\
\text { management }\end{array}$} & $\begin{array}{l}\text { * the habit of doing some simpler forestry work by hand (for example, with a } \\
\text { chain saw) }\end{array}$ \\
\hline & * the experience of using forestry machines \\
\hline & $\begin{array}{l}\text { * applying the skills of wood reprocessing (handicraft, building saunas and } \\
\text { boats, producing tar) }\end{array}$ \\
\hline & $\begin{array}{l}\text { * making themselves forest management tools or adjusting them to their own } \\
\text { needs }\end{array}$ \\
\hline & * the experience with reforestation \\
\hline & * using horses in the management of forest \\
\hline & * the habit of producing firewood \\
\hline & * the experience of building forest drainage \\
\hline & * making forest management plans and preparing documentation \\
\hline & $\begin{array}{l}\text { * the skills to outsource forest management works beneficially, write projects, } \\
\text { trade on the timber market }\end{array}$ \\
\hline & * educating and supervising in forestry issues \\
\hline
\end{tabular}




\section{The category of Respective codes}

analysis

Networking with
companions engaged
in CCF

* active media consumption in the issues of forestry, having a say in media in $\mathrm{CCF}$

Networking with neighbourhood about forest

* self-education in the issues of CCF (training, reading books, investigating scientific articles)

* have shown their forest to the people interested in forestry or CCF (e.g. during the study days)

* associate to the networks of forestry specialists or ecologists

* experiment knowingly with non-mainstream forest management practices (and involve risk to economic income)

* the properties neighbours are also sympathisers of CCF (makes it easier to follow as the mainstream support system does not recognise this forestry type)

* mutual cooperation in forestry management and sharing of tools or machines is common in the neighbourhood

* have acquired the skills and understandings about CCF from their ancestors

* have in forest management help from their future generations

* share or sell their forest products to local people, relatives, friends

* have agreements with neighbours about the principles of how to use the forest or to manage it (e.g. not to fall trees next to roads)

* cooperation with local micro-entrepreneurs who reprocess small quantities of wood (e.g. handicraft)

Cooperation with active-pragmatic - use the services when economically profitable, well-inmainstream forest formed about or even influences the activities of the local association associations

selective - use the services provided by association's if they can follow the owner's requirements

passive-pragmatic — occasionally use specific types the services

dependent - depend on the forest associations' consultants and their will

ideologically incompatible — do not want to cooperate because of ideological discrepancy

Acknowledgements Liis Kuresoo assisted with interviews. Asko Lõhmus and two anonymous reviewers made many constructive comments on the manuscript.

Funding This work was supported by the Estonian Research Council [grant number IUT 34-7 to LR; grant holder A. Lõhmus].

\section{References}

Adermann V (ed) (2012) Eesti metsad 2010. Estonian Environment Information Centre 159 pp. [Estonian forests 2010; in Estonian]

Aitsam V (ed) 2012 Metsaomaniku käsiraamat. Erametsakeskus, 288 pp.[Handbook for a forest owner; in Estonian] 
Alvela A (2019) Harvester - kellele looduse hävitaja, kellele arengutee sillutaja. Eesti Mets 1:22-28. [Harvester-some see it as a destroyer of the nature, others see it paving the way to development; in Estonian]

Axelsson R, Angelstam P (2011) Uneven-aged forest management in boreal Sweden: local forestry stakeholders' perceptions of different sustainability dimensions. Forestry 84:567-579. https://doi. org/10.1093/forestry/cpr034

Blanco V, Brown C, Rounsevell M (2015) Characterising forest owners through their objectives, attributes and management strategies. Eur J Forest Res 134:1027-1041. https://doi.org/10.1007/ s10342-015-0907-X

Daniel O (1936) Talumetsade korralduse võimalusi. Konjunktuur 17:246-249. [Possibilities of improving private forests; in Estonian with English summary]

Daymon C, Holloway I (2002) Qualitative Research Methods in Public Relations and Marketing Communications. Routledge, p 49. https://doi.org/10.4324/9780203846544

Eggers J, Lämås T, Lind T, Öhman K (2014) Factors influencing the choice of management strategy among small-scale private forest owners in Sweden. Forests 5:1695-1716. https://doi.org/10.3390/f5071695

EAS (2019) Turismi osa Eesti majanduses 2015 https://static1.visitestonia.com/docs/3449429_tsa2015. pdf [The share of tourism in Estonian economy; in Estonian]

Forest Act (2007) and 2009) Riigi Teataja I. Available at https://www.riigiteataja.ee/redaktsioonide vord lus.html?grupiId=305431\&vasakAktId=12790553\&paremAktId=13099666 [these wordings only in Estonian]

ELF (2019) The website of Estonian Fund for Nature, https://elfond.ee/metsaomanikule/demomets, used in March 2020. [Nature-friendly forestry demonstration site and a study path in Pokuland. in Estonian]

Environmental Board Lendorava elupaikade taastamine https://www.keskkonnaamet.ee/en/node/3647 [The restoration of the habitats of flying squirrel; in Estonian], see also https://ec.europa.eu/environment/life/project/Projects/index.cfm?fuseaction=search.dspPage\&n_proj_id=6797\&docType=pdf

ETIS (2020a) "Shelterwood method, selection cutting and continuous cover forestry demonstration-experimental areasnetwork and guidelines", project T200033MIME in Estonian Research Information System https://www.etis.ee/Portal/Projects/Display/ec2b6959-8c1d-40e3-ac01-1d229251a7d2?lang=ENG

ETIS (2020b) "The impact of selection cuttings on the carbon balance of forest ecosystem and economical aspects", project T200106MIME in Estonian Research Information System https:/www.etis.ee/ Portal/Projects/Display/fe0ead4f-feab-4ea1-a4a4-6f00ce1ed699?lang=ENG

ETFL (2018) Turismiettevõtete avalik pöördumine Eesti loodusvarade säästliku kasutamise asjus. Riigikogu keskkonnakomisjonile, Keskkonnaministrile, Majandusministrile. [Estonian Association of Travel Agents public appeal to parliament, Minister of Environment and Minister of Economic Affairs and Infrastructure regarding the sustainable use of Estonian natural resources; in Estonian]

Etverk I (2005) Taasiseseisvunud Eesti metsapoliitika ja — seadusandluse kujunemine (aastani 2005)

Eyvindson K, Duflot R, Triviño M, Blattert C, Potterf M, Mönkkönen M (2021) High boreal forest multifunctionality requires continuous cover forestry as a dominant management. Land Use Policy 100:104918. https://doi.org/10.1016/j.landusepol.2020.104918

Ezzy D (2002) Qualitative Analysis: Practice and Innovation. Routledge London

Ficko A, Lidestav G, Dhubháin AN, Karppinen H, Zivojinovic I, Westin K (2019) European private forest owner typologies: A review of methods and use. Forest Policy Econ 99:21-31. https://doi. org/10.1016/j.forpol.2017.09.010

Geels FW (2002) Technological transitions as evolutionary reconfiguration processes: a multi-level perspective and case-study. Res Policy 31:1257-1274. https://doi.org/10.1016/S0048-7333(02)00062-8

Geels FW (2004) From sectoral systems of innovation to socio-technical systems: Insights about dynamics and change from sociology and institutional theory. Res Policy 33:897-920. https://doi.org/10.1016/j. respol.2004.01.015

Geels FW, Schot J (2007) Typology of socio-technical transition pathways. Res Policy 36:399-417. https://doi.org/10.1016/j.respol.2007.01.003

Geels FW, Tyfield D, Urry J (2014) Regime resistance against low-carbon transitions: Introducing politics and power into the multi-level perspective. Theory Cult Soc 31:21-40. https://doi.org/10.1177 $\% 2 \mathrm{~F} 0263276414531627$

Geels FW, Sovacool BK, Schwanen T, Sorrell S (2017) Sociotechnical transitions for deep decarbonization. Science 357:1242-1244. https://science.sciencemag.org/content/357/6357/1242 
Geels FW (2020) Micro-foundations of the multi-level perspective on socio-technical transitions: Developing a multi-dimensional model of agency through crossovers between social constructivism, evolutionary economics and neoinstitutional theory. Technol Forecast Soc 152:119894. https://doi. org/10.1016/j.techfore.2019.119894

Giessen L (2013) Reviewing the main characteristics of the international forest regime complex and partial explanations for its fragmentation. Int Forest Rev 15:60-70. https://doi. org/10.1505/146554813805927192

Hayter R, Clapp A (2020) Towards a collaborative (public-private partnership) approach to research and development in Canada's forest sector: an innovation system perspective. Forest Policy Econ 113:102119. https://doi.org/10.1016/j.forpol.2020.102119

Helliwell R, Wilson E (2012) Continuous Cover Forestry in Britain: challenges and opportunities. Q J Forest 106:214-224

Instruction for forest inventory (2018) Riigi Teataja I. Available at https:/www.riigiteataja.ee/akt/13124148 [in Estonian]

Investment support for forest development and forest health (2018) Riigi Teataja I. Available at https:// www.riigiteataja.ee/akt/113052015001 [in Estonian]

Juutinen A, Ahtikoski A, Mäkipää R, Shanin V (2018) Effect of harvest interval and intensity on the profitability of uneven-aged management of Norway spruce stands. Forestry 91:589-602. https://doi. org/10.1093/forestry/cpy018

Juutinen A, Tolvanen A, Koskela T (2020) Forest owners' future intentions for forest management. Forest Policy Econ 118:102220. https://doi.org/10.1016/j.forpol.2020.102220

Kiisel M, Kasemets M, Hõrak H (2018) Sihtrühmade ootused metsanduse arengukavale. Tartu Ülikooli Sotsiaalteaduslike Rakendusuuringute Keskus. pp. [The target groups' expectations to Forestry Development Plan; in Estonian], p 54

Kim S, Axelsson EP, Girona MM, Senior JK (2021) Continuous-cover forestry maintains soil fungal communities in Norway spruce dominated boreal forests. Forest Ecol Manag 480:118659. https://doi. org/10.1016/j.foreco.2020.118659

Kleinschmit D, Pülzl H, Secco L, Sergent A, Wallin I (2018) Orchestration in political processes: Involvement of experts, citizens, and participatory professionals in forest policy making. Forest Policy Econ 89:4-15. https://doi.org/10.1016/j.forpol.2017.12.011

Kosenkranius T (2016) Usewoodi minimetsamasinad. Sinu Mets 44:6-7. [Usewood small forestry machines; in Estonian]

Kuuluvainen T, Gauthier S (2018) Young and old forest in the boreal: critical stages of ecosystem dynamics and management under global change. For Ecosyst 5:26. https://doi.org/10.1186/s40663-018-0142-2

Laas E, Uri V, Valgepea M (eds) (2011) Metsamajanduse alused. Õpik kõrgkoolidele. Tartu Ülikooli Kirjastus $862 \mathrm{pp}$. [Basics in forestry. Textbook for universities and colleges; in Estonian]

Laik J (2018) Turismiettevõtjat teevad murelikuks turistide küsimused Eesti metsa kohta. Pärnu Postimees March 14th 2018. https://parnu.postimees.ee/4439175/turismiettevotjat-teevad-murelikuks-turistidekusimused-eesti-metsa-kohta [Tourism entrepreneurs are concerned because of the tourists' questions about the Estonian forests; in Estonian]

Lindstad BH (2018) 'What's in it for me?'-Contrasting environmental organisations and forest owner participation as policies evolve. Forest Policy Econ 89:80-86. https://doi.org/10.1016/j. forpol.2017.01.003

Lindenmayer DB, Franklin JF, Lõhmus A, Baker SC, Bauhus J, Beese W, Brodie A, Kiehl B, Kouki J, Pastur GM, Messier C, Neyland M, Palik B, Sverdrup-Thygeson A, Volney J, Wayne A, Gustafsson L (2012) A major shift to the retention approach for forestry can help resolve some global forest sustainability issues. Conserv Lett 5:421-431. https://doi.org/10.1111/j.1755-263X.2012.00257.X

Lõhmus A, Kraut A (2010) Stand structure of hemiboreal old-growth forests: characteristic features, variation among site types, and a comparison with FSC-certified mature stands in Estonia. Forest Ecol Manag 260:155-165. https://doi.org/10.1016/j.foreco.2010.04.018

Lovrić N, Lovrić M, Mavsar R (2020) Factors behind development of innovations in European forestbased bioeconomy. Forest Policy Econ 111:102079. https://doi.org/10.1016/j.forpol.2019.102079

Lõhmus A, Fridolin H, Leivits A, Tõnisson K, Rannap R (2019) Prioritizing research gaps for national conservation management and policy: the managers' perspective in Estonia. Biodivers Conserv 28:2565-2579. https://doi.org/10.1007/s10531-019-01779-8

Maier C, Lindner T, Winkel G (2014) Stakeholders' perceptions of participation in forest policy: A case study from Baden-Württemberg. Land Use Policy 39:166-176. https://doi.org/10.1016/j. landusepol.2014.02.018 
McMahon P, Sarshar D, Purser P (2016) Investing in continuous cover forestry. White paper. SLM Partners, p 24

Meikar T (2001) Dauerwaldist looduslähedase metsamajanduseni Eestis. Akadeemilise Metsaseltsi toimetised 11:52-91. [From "Dauerwald" to sustainable forest management in Estonia; in Estonian with English summary]

Meikar T, Etverk I (2000) Metsaomand Eestis. Forestry Studies 32:8-18. [Forest ownership in Estonia, in Estonian with English summary]

Miina J, Pukkala T, Kurttila M (2016) Optimal multi-product management of stands producing timber and wild berries. Eur J Forest Res 135:781-794. https://doi.org/10.1007/s10342-016-0972-9

Ministry of the Environment (2018) Meetings for starting the composing of the forestry development plan for 2021-2030. Available at https://www.envir.ee/et/mak2030-algatamise-tooruhma-kohtumised, visited February 6th 2019

Möller A (1922) Der Dauerwaldgedanke. Sein Sinn und seine Bedeutung. Springer. https://doi. org/10.1007/978-3-642-50866-0

Nieminen M, Hökkä H, Laiho R, Juutinen A, Ahtikoski A, Pearson M, Kojola S, Sarkkola S, Launiainen S, Valkonen S, Penttilä T (2018) Could continuous cover forestry be an economically and environmentally feasible management option on drained boreal peatlands? Forest Ecol Manag 424:78-84. https://doi.org/10.1016/j.foreco.2018.04.046

Örd A (2000) Kaitsemetsad ja nende majandamine Eestis. Ministry of Environment \& DANCE, Tartu [Protection forests and their management in Estonia. in Estonian]

Org R (2018) Metsaühistu liikmete rahulolu erametsanduse tugisüsteemi ja selle teenustega [Bachelor thesis]. Estonian University of Life Sciences, $40 \mathrm{pp}$. [Satisfaction of forestry association members with private forest support system and its services; in Estonian with English summary]

Peura M, Burgas D, Eyvindson K, Repo A, Mönkkönen M (2018) Continuous cover forestry is a cost-efficient tool to increase multifunctionality of boreal production forests in Fennoscandia. Biol Conserv 217:104-112. https://doi.org/10.1016/j.biocon.2017.10.018

Põllumäe P, Korjus H, Paluots T (2014) Management motives of Estonian private forest owners. Forest Policy Econ 42:8-14. https://doi.org/10.1016/j.forpol.2014.02.007

Puettmann KJ, Wilson SM, Baker SC, Donoso PJ, Drössler L, Amente G, Harvey BD, Knoke T, Lu Y, Nocentini S, Putz FE, Yoshida T, Bauhus J (2015) Silvicultural alternatives to conventional evenaged forest management-what limits global adoption? For Ecosyst 2:1-16. https://doi.org/10.1186/ s40663-015-0031-x

Pukkala T, Lähde E, Laiho O (2012) Continuous cover forestry in Finland-recent research results. In: In: Pukkala T, Gadow K (eds) Continuous Cover Forestry, Second edn. Springer Science \& Business Media, pp 85-128. https://doi.org/10.1007/978-94-007-2202-6_3

Ramiah V, Gregoriou GN (eds) (2016) Handbook of environmental and sustainable finance. Academic Press, 479 pp. https://doi.org/10.1016/C2014-0-05175-1

Raudsaar M, Siimon KL, Valgepea M (eds) (2017) Yearbook forest 2016. Estonian Environmental Agency, p 293

Raudsaar M, Siimon KL, Valgepea M (eds) 2018 Yearbook forest 2017.Estonian Environmental Agency,292pp

Remm L, Rünkla M, Lõhmus A (2018) How bilberry pickers use Estonian forests: implications for sustaining a non-timber value. Balt For 287-295

Remm L, Rünkla M, Kuresoo L (2020) Teejuht püsimetsandusse. Estonian Fund for Nature, 142 pp. [A guide to the continuous cover forestry; in Estonian]

Requirements for applying and providing subsidies in private forestry (2021) Riigi Teataja I. Available at https:/www.riigiteataja.ee/akt/119012021010 [in Estonian]

Ruukel A (2020) Aivar Ruukel: turism ei ole metsanduse alternatiiv.ERR News(13.01.2020 [Tourism is not an alternative to the forestry; in Estonian]

Ruukel A, Rähni B (2017) Turismiettevõtete ja -ühenduste avalik pöördumine Eesti metsa säästvaks majandamiseks. Riigikogu keskkonnakomisjonile ja keskkonnaministrile. [Tourism companies' and associations' public appeal to parliament and. Minister of Environment for the sustainable management of Estonian forests; in Estonian]

Schabak E (1931) Talumetsade korraldamisest. Eesti Mets 7:199-201. [About planning and managing farm forests; in Estonian]

Sorrell S (2018) Explaining sociotechnical transitions: A critical realist perspective. Res Policy 47:12671282. https://doi.org/10.1016/j.respol.2018.04.008 
Statistics Estonia (2018) Väliskülastajate uuring 2016-2017. https:/www.puhkaeestis.ee/et/uuringud-jaulevaated/valiskulastajate-uuring-2016-2017 [Survey of foreign visitors; in Estonian]

Statistics Estonia (2019) Database: https:/www.stat.ee/database

Stoettner EM, Dhubháin ÁN (2019) The social networks of Irish private forest owners: an exploratory study. Forest Policy Econ 99:68-76. https://doi.org/10.1016/j.forpol.2017.09.008

Tarn H, Bole O (eds) (2018) (assignee) Method for producing laminate floorboards having edges following the natural curvature of the wooden material. US patent 9,951,530 B2

Tomao A, Bonet JA, de Aragón JM, de-Miguel S (2017) Is silviculture able to enhance wild forest mushroom resources? Current knowledge and future perspectives. Forest Ecol Manag 402:102-114. https://doi.org/10.1016/j.foreco.2017.07.039

Turu-uuringute AS (2018) Eesti elanike keskkonnateadlikkuse uuring. Available at https://www.envir. ee/sites/default/files/2018_keskkonnateadlikkuse_uuring.pdf. [Environmental awareness survey of Estonian residents; in Estonian]

Turu-uuringute AS (2019) Erametsaomanike küsitlusuuring. Available at https:/www.eramets.ee/wp-content/uploads/2019/10/Erametsaomanike-uuringu-2019-aruanne.pdf. [Private forest owners survey; in Estonian]

van Beers C, van den Bergh JC (2001) Perseverance of perverse subsidies and their impact on trade and environment. Ecol Econ 36:475-486. https://doi.org/10.1016/S0921-8009(00)00245-7

Venter ZS, Barton DN, Gundersen V, Figari H, Nowell M (2020) Urban nature in a time of crisis: recreational use of green space increases during the COVID-19 outbreak in Oslo, Norway. Environ Res Lett 15:104075. https://doi.org/10.1088/1748-9326/abb396

Viiron K (2020) Erakordne kevad loodusradadel. Metsamees 139:16-19. [Emergency situation on nature trails; in Estonian]

Vihma P, Toikka A (2021) The limits of Collaborative Governance: The role of inter-group learning and trust in the case of the Estonian "Forest War". Environ Policy Gov 31:403-416. https://doi. org/10.1002/eet.1952

Weber N (2018) Participation or involvement? Development of forest strategies on national and sub-national level in Germany. Forest Policy Econ 89:98-106. https://doi.org/10.1016/j.forpol.2017.04.002

Weiss G, Ludvig A, Zivojinovic I, Asamer-Handler M, Huber P (2017) Non-timber innovations: How to innovate in side-activities of forestry_Case study Styria, Austria. Austria J of For Sci 134:231-250

Publisher's Note Springer Nature remains neutral with regard to jurisdictional claims in published maps and institutional affiliations.

\section{Authors and Affiliations}

\section{Maie Kiisel ${ }^{1} \cdot$ Liina Remm $^{2}$}

\section{Liina Remm \\ liina.remm@ut.ee}

1 Johan Skytte Institute of Political Studies, University of Tartu, Lossi 36, EE-51003 Tartu, Estonia

2 Department of Zoology, Institute of Ecology and Earth Sciences, University of Tartu, Liivi Street 2, EE-50409 Tartu, Estonia 